\title{
BANK CREDIT AND PRODUCTIVITY: EVIDENCE FROM MEXICAN FIRMS
}

\author{
Mario Villalpando* \\ BANCO DE MÉXICO
}

(Received December 19, 2013, accepted March 25, 2014)

\begin{abstract}
$\overline{\text { Abstract }}$
Using a recent survey of Mexican firms, this paper provides empirical evidence for the hypothesis that bank credit improves the productivity of firms with investment opportunities. On average, firms with access to bank credit and investment opportunities are 50 percent more productive than other firms. Bank credit and investment opportunities are instrumented by firms' collateral and spending on utilities to overcome potential biases of OLS estimates. The results are consistent with both OLS and IV estimates.
\end{abstract}

\section{Resumen}

Con base en una encuesta reciente de empresas mexicanas, en este artículo presenta evidencia empírica que favorece la hipótesis de que el crédito bancario promueve la productividad de las empresas. En promedio, las empresas con acceso al crédito bancario y oportunidades de inversion son 50 por ciento más productivas que otro tipo de empresas. Para evitar problemas de sesgo en los parámetros de mínimos ordinarios cuadrados (MCO), las variables de crédito bancario y oportunidades de inversion son instrumentadas por las garantías y gasto en servicios de energía y comunicaciones de las empresas. Los resultados son consistentes independientemente si son estimados con $\mathrm{MCO}$ o variables instrumentales.

JEL Classification: G33, D24 J26.

Keywords: Bank Credit; Firms' Productivity; Labor Productivity.

* Banco de México, Av. 5 de Mayo No. 1, Centro, México, D.F. C.P. 06059. E-mail: villalpa@banxico.org.mx. Any opinions and conclusions expressed herein are those of the author and do not necessarily represent the views of Banco de Mexico.

Valuable comments were received from participants at the 18th. Annual LACEA meeting in Mexico City, 2013. 


\section{Introduction}

The productivity of firms in Mexico and other developing countries is very low. Low productivity is more common among small firms and Mexico has an overabundance of extremely small firms (around 90 percent of all firms). Scarce credit partially explains the uneven productivity, especially among smallsized firms. Many productive firms cannot expand or make the technological improvements and investments needed to increase their productivity because they have no access to bank credit (Bloom, et. al., 2010; Lora y Pages, 2011).

This paper tests empirically the hypothesis that bank credit increases the productivity of firms (Schiantarelli and Jaramillo, 1999; Gatti and Love 2006). Different rates of return and productivity exist for different sources of external finance. There is a preference ordering for the relevant finance where access to it is dictated by its cost (Keasey and McGuinness, 1990). Although, firms prefer to use internal finance first for making investments to avoid paying a premium for external finance (Myers, 1984), credit allows them to invest beyond what their internal funds can support. ${ }^{1}$

Banks have better information on other credit suppliers resulting from economies of scale and the comparative advantages of information gathering. Based on their cost and informational advantage, banks can offer better contract terms to firms than other available sources of financing ${ }^{2}$ (Berger and Udell, 1995; Rajan and Zingales, 2003; Pages, 2010). In this regard, Keasey and McGuinness (1990) found that "small new firms are more efficient in their use of funds when they are answerable to, and are monitored by, private sector banks". A more efficient use of bank credit leads to higher returns and productivity levels.

However, firms with credit access but without profitable opportunities will divert funds to non-investment uses, such as the financing of daily operations (Ghani and Suri, 1999; Butler and Cornaggia, 2007). Thus, credit without investment opportunities may be inefficient. The channel of transmission from credit to productivity is in its efficiency, rather than its volume, (De Gregorio and Guidotti 1995).

In brief, this paper tests the hypothesis that bank credit improves the productivity of firms with investment opportunities or expansion plans. ${ }^{3}$ Enterprises with access to credit but without expansion plans will divert these resources to different uses, such as financing their daily operations, so bank credit will not have a significant effect on productivity.

The outline of this paper is as follows. The next section describes the data and the determinants of productivity. This includes a description of the control

\footnotetext{
1 Credit access should make a disproportionate improvement to productivity in firms that are technologically more dependent on external funds.

2 Alternative suppliers of credit may not monitor efficiently the use of loans extended to them. For instance, trade credit is not usually granted to maximize a firms' return, but as a matter of exchange custom and to secure customer loyalty (Keasey and McGuinness, 1990).

3 Banks are assumed to identify firms with productive investments. Furthermore, banks efficiently align the incentives of a firm's management with the interest of bank officers through clever contracts and speedy enforcement.
} 
variables. The third section describes the methodology including a discussion on the variables used to select the firms with investment opportunities. Section 5 describes the empirical results and some methodological issues are addressed, such as the potential problem of endogeneity in the estimates. Section 5 contains the conclusion. Finally, the appendix describes the definitions and sources of the variables used in the study.

\section{Data Description and Determinants of Productivity}

The data used in this study come from the Survey of Enterprises on Competitiveness, Financing and Use of Financial Services ${ }^{4}$ conducted by the National Banking Commission and Inter-American Development Bank (2009). The survey collects information of sources and terms of financing and use of financial services, including data on firm profiles and characteristics of ownership, as well as measures of competitiveness. The survey includes information of 986 non-financial firms with more than 5 employees in localities with at least 50 thousand inhabitants. Firms are grouped in four size categories (micro, small, medium and large) according to the number of employees (see Appendix for more information).

\subsection{Labor Productivity}

The analysis is based on labor productivity ${ }^{5}(L P)$ measured as the output $(y)$ to labor ratio $(l)$ :

$$
L P=\frac{y}{l}
$$

Labor is measured as the number of employees per firm. Output is computed as firm's total income weighted by an aggregate output price index at the sector level (industry, trade and services). Figure 1 shows the firm-level distribution of productivity. ${ }^{6}$ LP dispersion is wide. This result is found in other countries (Bartelsman and Doms, 2000).

There is a positive relationship between firm size and productivity. As can be seen in Table 1, medium- and large-size enterprises have higher productivity levels than smaller ones (Leung, et. al., 2008). A small-sized firm is 52 percent less productive than a large-sized firm. The observed labor dispersion suggests resource allocation problems, so an efficient allocation would' improve the aggregate productivity (Hsie and Klenow, 2009). The relationship between firm size and productivity also varies among economic sectors as seen in Figure 2 (Rajan and Zingales, 1998).

The dispersion of firms' LP has been an inconclusive issue in the specialized literature. In a competitive market with free entry and exit of

\footnotetext{
4 "Encuesta Nacional de Competitividad, Fuentes de Financiamiento y Uso de Servicios Financieros de las Empresas".

5 LP is used for several reasons. LP is an informative measure of firms' unit labor cost, which is employed by entrepreneurs to make decisions on profitable opportunities. LP is a well-known variable for evaluating firms' efficiency. LP is highly correlated with total factor productivity measures (TFP). Both, LP and TFP, are the main productivity variables used for research purposes (Bartelsman and Doms, 2000; Baily, et. al., 2001; Baily and Solow, 2001; Easterly, 2001).

6 Data limitations allow the estimation of LP for a total of 369 firms.
} 
firms, the economic theory predicts that firms with low productivity will exit and more productive firms will enter the market (Bartelsman and Doms, 2000).

Figure 1. Distribution of Firm-Level Labor Productivity (Logs)

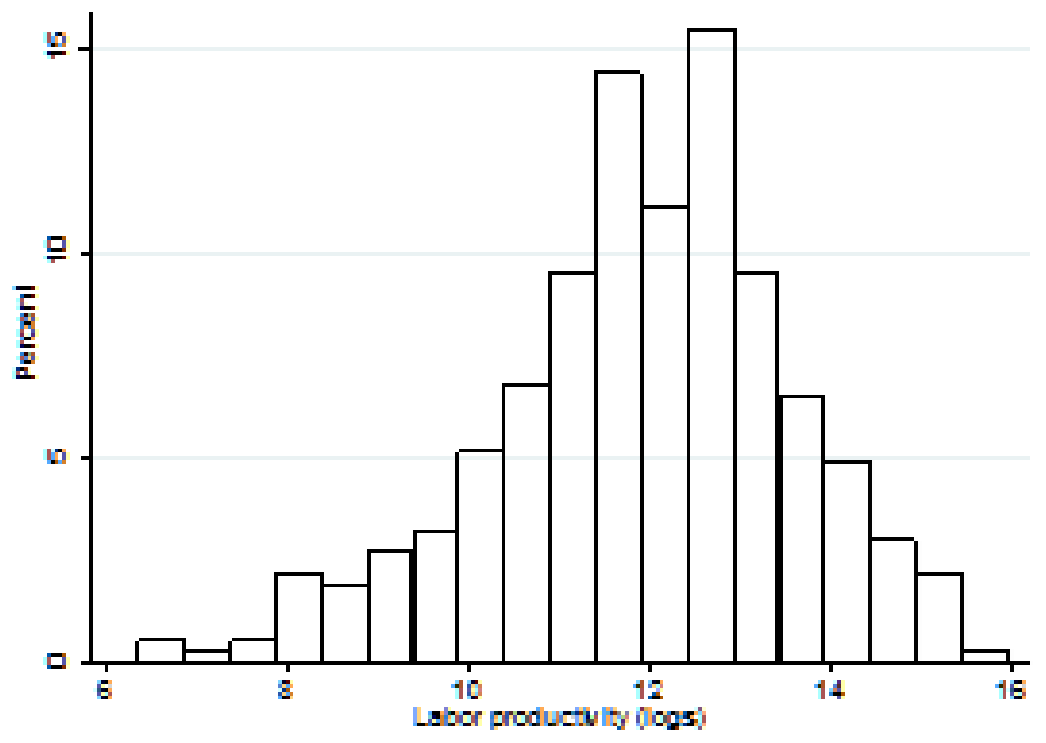

Table 1. Descriptive Statistics of LP and LP Relative Index by Firm Size

\begin{tabular}{lc|cc|c}
\hline Firmsize & Average & $\begin{array}{c}\text { Standard } \\
\text { Deviation } \\
1.62\end{array}$ & $\begin{array}{c}\text { Number of } \\
\text { observations }\end{array}$ & $\begin{array}{c}\text { Relative } \\
\text { Index }\end{array}$ \\
Micro & 11.47 & 138 & 62.6 \\
S mall & 11.83 & 1.62 & 111 & 52.1 \\
Medium & 12.68 & 1.57 & 52 & 122.5 \\
Large & 12.48 & 1.43 & 68 & 100.0 \\
\hline All firms & 11.93 & 1.64 & 369 & n.a.
\end{tabular}

Notes: LP measured in logs; the relative index is constructed as the LP for each firm size with respect to large firms, in other words, it measures firms' LP with respect to large firms. 
Figure 2. LP by Firm Size and Economic Sector

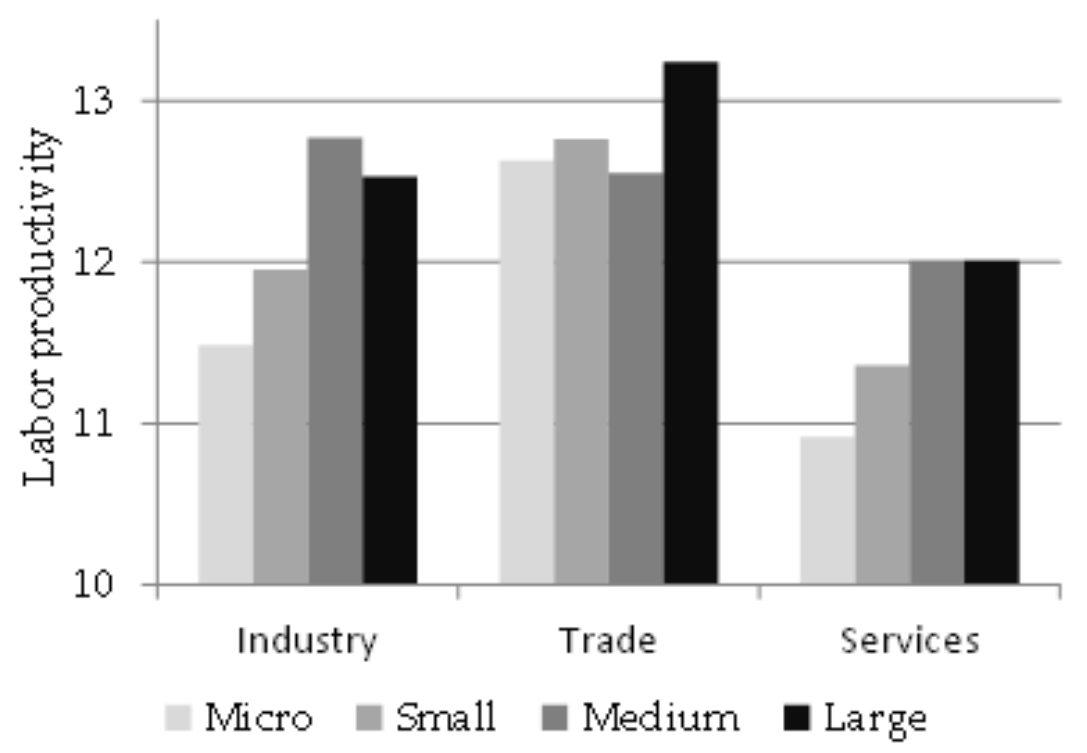

Note: LP measured in logs.

\subsection{Determinants of Productivity}

Studies in other countries have found that industries are characterized as collections of heterogeneous-productivity producers. Firms with low productivity coexist with their high-productivity counterparts (Alfaro, et. al., 2008). Businesses' measured productivity levels are persistent and vary significantly within industries, suggesting that productivity has an inherent idiosyncratic element. To identify the effects of bank credit on productivity, the effects of other factors must be controlled in the empirical estimate. The following is a discussion on some of those factors.

"Competition is the main driver of productivity. In this paper, this factor is measured by firms' foreign sales. A key prediction of some international trade models is that only the most productive firms succeed in exporting while the least productive firms survive entirely on their sales in the domestic market" (Tybout and Roberts, 1997; Melitz, 2003 and Bernard, et. al., 2003). Table 2 shows evidence that export-oriented firms -defined as firms with export sales that exceed 50 percent of total revenue- have higher levels of productivity than other types of firms. 
Table 2. LP of Export and Non-Export Oriented Firms ${ }^{1 /}$

\begin{tabular}{|l|c|c|}
\hline Firm size & $\begin{array}{c}\text { Export-oriented } \\
\text { firms }^{2}\end{array}$ & $\begin{array}{c}\text { Non export- } \\
\text { oriented firms }\end{array}$ \\
\hline Micro & 12.4 & 11.4 \\
\hline S mall & 12.7 & 11.8 \\
\hline Medium & 14.0 & 12.5 \\
\hline Large & 12.6 & 12.5 \\
\hline All firms & 12.1 & 11.7 \\
\hline
\end{tabular}

$1 /$ LP in logs. The difference between export-oriented and non-export-oriented firms is statistically significant at the 5 percent level.

2/ Firms with export sales that exceed 50 percent of total revenue.

Human capital is regarded as one of the main factors affecting 5roductivity. Some studies based on firm-level data have found that the best human resources are concentrated in capital-intensive industries, which are usually large-sized firms, while low-skill workers are located in micro and small sized firms (Abowd, et. al., 2002). Table 3 shows similar patterns in Mexican firms. Workers with more years of education are concentrated in medium- and large-sized firms.

Table 3. Workers by Level of Education ${ }^{1 /}$ (Percentages)

\begin{tabular}{|l|ccc|}
\hline Firm size & $\begin{array}{c}\text { Workers with } \\
\text { basic education }\end{array}$ & $\begin{array}{c}\text { Workers with } \\
\text { second ary } \\
\text { education }\end{array}$ & $\begin{array}{c}\text { Workers } \\
\text { with college } \\
\text { ed ucation }\end{array}$ \\
\hline Micro & 51.1 & 31.5 & 17.4 \\
\hline Smal1 & 46.8 & 28.6 & 24.6 \\
\hline Medium & 47.8 & 31.3 & 20.9 \\
\hline Large & 46.2 & 30.3 & 23.5 \\
\hline All firms & 48.5 & 30.5 & 21.2 \\
\hline
\end{tabular}

$1 /$ Total number of permanent and temporary workers.

Decision-making in the firm also affects productivity. In developing countries, there is an abundance of family owned firms, where family members control the business and make the important decisions. In some family firms, owners are not entrepreneurs. Lack of entrepreneurship explains why some low-productivity firms remain in some "natural" small scale industries. ${ }^{7}$ Small business owners have "little desire to grow big or to innovate in any observable way" and may pursue non-pecuniary benefits (Hurst and Pugsley, 2011).

\footnotetext{
7 Some examples of small-scale industries are plumbers, electricians, contractors, painters, skilled professionals, insurance and real estate agents and small shopkeepers.
} 
In family firms, because entrepreneurial ability is not necessarily related to family ties, directors do not always make the best decisions, thus reducing the firm's efficiency (Bloom, et. al., 2010). Badly managed firms and entrepreneurs pursuing non-pecuniary benefits combined with a "natural" small scale of some industries explain why some firms do not grow and maintain low levels of productivity.

At odds with small-sized firms, Maury (2006) found that in large firms active family control is associated with higher profitability compared to non-family firms because family control reduces the agency problem between owners and managers.

Three variables are included in the empirical estimate for the factors associated with family enterprises. One variable indicates that if directors are relatives of owners, the second one indicates when the owner is the general manager and the third one is a measure of external control -where external shareholders own 50 per cent or more of the firm's capital. Table 4 shows that a larger proportion of micro and small sized firms are family-owned with active family control and scarce external participation. More than half of large firms are family controlled. The bottom part of Table 4 shows firms LP and selected measures of internal decision making. The data show no significant differences in productivity among family-owned firms, firms where the owner is the general manager and firms with external control.

The prevalence of a large informal sector also helps to explain firms' productivity. Pages (2010) showed that a complex taxation system negatively affects firms' productivity. At the firm level, ill-designed taxes are an incentive for firms to dedicate time and money to avoid them, diverting resources from more productive uses. At the same time, some public policies to promote job creation favor small and medium enterprises (SME) whatever their productivity levels, shifting employment away from large firms in an inefficient manner.

There are also compelling reasons for the small entrepreneur to join the tax net. For SME, participation in the tax regime brings a firm into the formal sector, allowing it to access formal credit markets, government procurement, and access to markets including those for export.

Given the relevance of formality on productivity, the empirical estimate includes an index of formality based on the following variables:

1. Fiscal regime: a) sole proprietorship, b) limited liability partnerships or c) corporations. ${ }^{8}$

2. Registry of business operations: a) no bookkeeping, b) owner keeps transaction books, c) the firm has a certified accountant to keep the books or the firm has a certified cash register (SHCP).

3. Sales receipts: a) no receipts, b) only receipts, d) receipts and invoices. ${ }^{9}$

8 These terms correspond roughly to the following Spanish terms: a) persona física sin actividad empresarial, b) persona física con actividad empresarial y c) persona moral.

9 These terms correspond roughly to the following Spanish terms: a) no emite recibos ni facturas, b) sólo emite recibos y c) emite facturas y recibos o cuenta con caja registradora de SHCP. 
4. Business licensing. Firm is registered with the IRS, county, ministry of economy, secretary of health, etc.

Table 4. Decision-Markers in the Firm and Productivity by Firm Size

\begin{tabular}{|l|c|c|c|}
\hline Firm size & $\begin{array}{c}\text { Family- } \\
\text { owned firm }\end{array}$ & $\begin{array}{c}\text { Owner is } \\
\text { general director }\end{array}$ & $\begin{array}{c}\text { Firm with } \\
\text { external control }\end{array}$ \\
\hline \multicolumn{4}{|c|}{ Number of firms $\%$} \\
\hline Micro & 66.5 & 89.3 & 13.1 \\
Smal1 & 52.6 & 82.8 & 9.7 \\
Medium & 50.0 & 81.0 & 10.3 \\
Large & 36.6 & 54.3 & 30.3 \\
\hline \multicolumn{4}{|c|}{ Labor Productivity (logs) } \\
\hline Micro & 12.2 & 12.3 & 11.5 \\
Smal1 & 12.9 & 12.9 & 12.9 \\
Medium & 15.1 & 15.1 & 15.8 \\
Large & 15.6 & 15.9 & 15.0 \\
\hline
\end{tabular}

Based on the above variables an index of formality is constructed. This index has a range of 0 to 8 with 8 being a firm inside the formal system (Table 5 ). Figure 3 suggest a positive relationship between the degree of formality and productivity. A plausible explanation of this finding is that the more productive firms have more incentives to be formal.

In the empirical estimate, the above-mentioned factors are included in an attempt to control their effect on productivity with the following expected results.

1. A positive relationship between firm size and productivity.

2. The existence of idiosyncratic differences among economic sectors.

3. Firms with a larger proportion of foreign sales are expected to have higher levels of productivity.

4. Concentration of skilled workers in large-sized firms with higher levels of productivity.

5. Formal firms are more productive than informal ones.

Table 5. Index of Formality

\begin{tabular}{|c|c|c|c|}
\hline Fiscal regime & $\begin{array}{c}\text { Informality } \\
\text { proprietorship }\end{array}$ & $\begin{array}{c}\text { Limited liability } \\
\text { partners hips }\end{array}$ & Formality \\
\hline $\begin{array}{c}\text { Registry of } \\
\text { business } \\
\text { operations }\end{array}$ & $\begin{array}{c}\text { No } \\
\text { bookkeeping }\end{array}$ & $\begin{array}{c}\text { Owner leeps } \\
\text { transaction books }\end{array}$ & $\begin{array}{c}\text { Firm has a } \\
\text { certified accountant }\end{array}$ \\
\hline Sales receipts & No receipts & Receipts & $\begin{array}{c}\text { Receipts and } \\
\text { invoices }\end{array}$ \\
\hline $\begin{array}{c}\text { Business } \\
\text { licensing }\end{array}$ & $\begin{array}{c}\text { With one } \\
\text { authority }\end{array}$ & $\begin{array}{c}\text { With two } \\
\text { authorities }\end{array}$ & $\begin{array}{c}\text { With more than } \\
\text { two anthorities }\end{array}$ \\
\hline
\end{tabular}


Figure 3. Index of Formality and Firms' $L P^{*}$.

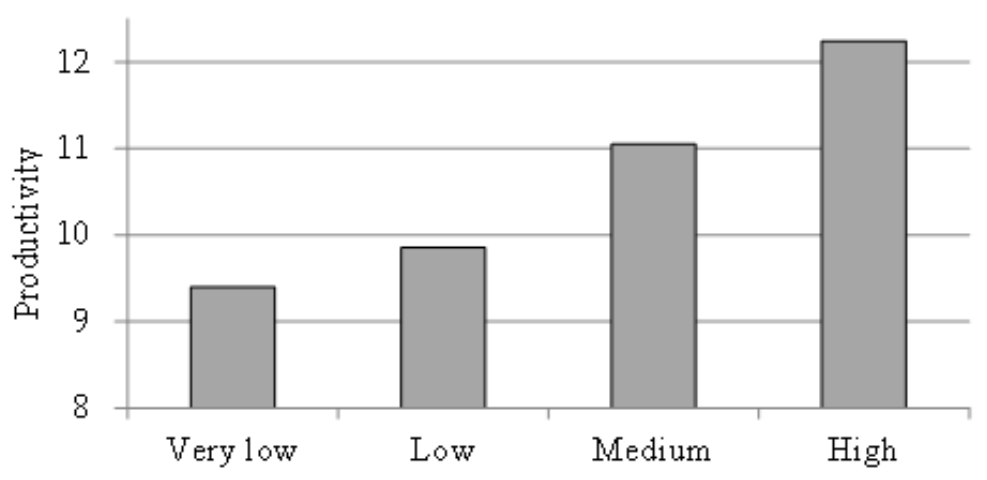

* Index of formality: Very low (0 - 3); Low (4 - 5); Medium (6 - 7) and High (8). LP is in $\log \mathrm{s}$.

\section{Methodology}

This section tests empirically the hypothesis that bank credit enhances firms' productivity. Figure 4 illustrates the strategy used to test this hypothesis. Initially, firms with investment opportunities are identified. With these firms, two groups of enterprises are formed. One group includes only firms with access to bank credit and the other group shows firms with alternative sources of finance. Under the assumption that banks can offer better credit terms, we examine whether firms with access to bank credit have relatively higher levels of productivity than the other group of firms (Berger and Udell, 1995; Rajan and Zingales, 2003; Pages, 2010).

Figure 4. The Relationship between Credit and Productivity

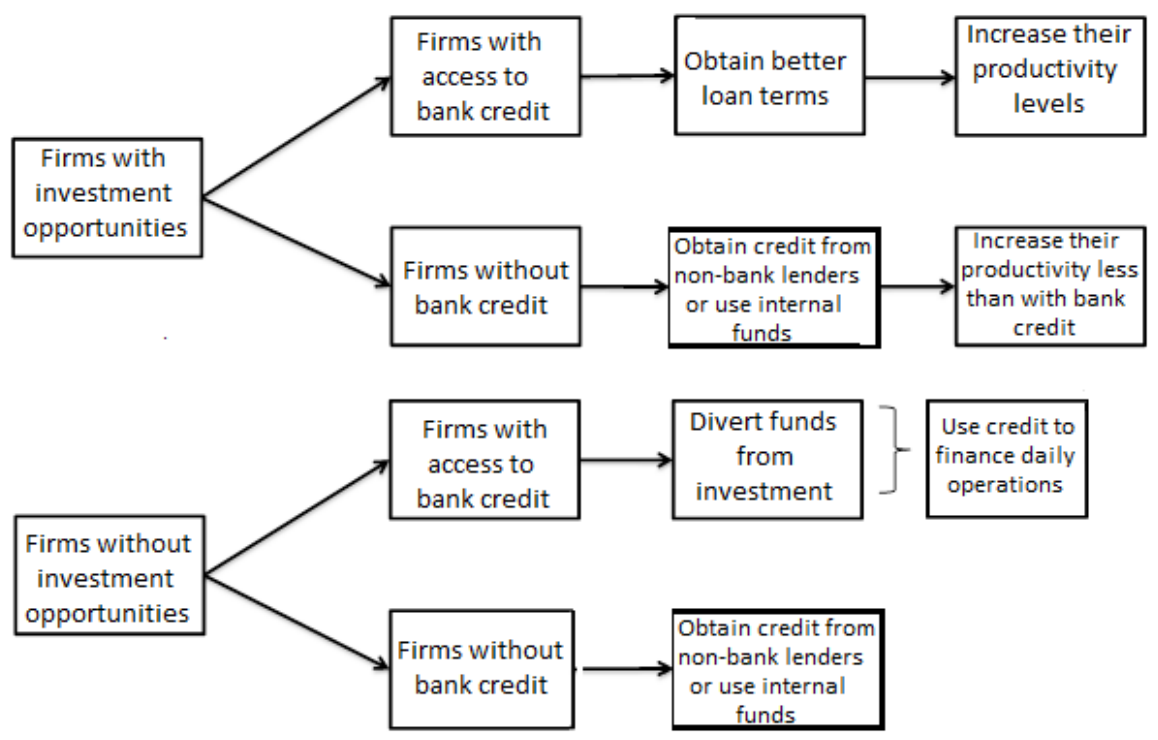


Econometrically, the hypothesis is tested using the following model:

$$
\begin{aligned}
& \text { Labor productivity } \mathrm{i}_{\mathrm{i}}=\text { Constant }+\sum\left(\gamma_{\text {is }} \text { Control variables }_{\mathrm{i}}\right)+ \\
& \beta\left(\text { Investment opportunities }_{\mathrm{i}} \text { Bank }_{\text {credit }}\right)+\varepsilon_{\mathrm{i}}
\end{aligned}
$$

Productivity is measured in $\operatorname{logs}$ for each firm indexed by $i$. The Greek letters $\beta$ and $\gamma$ represent parameters and $\varepsilon$ is an error term with the usual properties. The control variables (indexed by s) are the following.

1. Firm size and firm age attempt to control for productivity dispersion and heterogeneity. Size and age are positively related to productivity levels, so positive coefficients on these variables are expected.

2. Economic sector. Data show that capital intensive firms have higher productivity levels. There could be a technological reason why some firms are more capital-intensive than others. The initial project scale, the gestation period and the cash harvest period are different among sectors.

3. Workers' years of education, as a proxy of human capital.

4. Export-oriented firms. Firms with larger foreign sales also have higher levels of productivity.

5. Decision-maker. As discussed in the previous section, whether the owner or some other person is the key decision-maker for investment choices affects productivity. In this regard, three variables are considered. In a family-owned firm, the owner is the general manager of the firm.

6. The firm's degree of formality. Firms operating in the informal sector have limited capital, low technology and less-skilled workers, so their productivity level is below the industry average.

The hypothesis that bank credit enhances the productivity of firms with investment opportunities is tested through the interaction of two dichotomous variables $(0,1):$ i) investment opportunities and ii) bank credit. The significance of parameter $\beta$ will indicate that bank credit promotes productivity.

\subsection{The Proxy for Firms with Investment Opportunities}

Firms with investment opportunities are selected by means of a question on managers' expectations for investment plans in the next two years. ${ }^{10}$ Here, it is assumed that there is a relationship between investment opportunities and the need to buy capital. The relevance of this question and its relationship with bank credit is analyzed in the upper half of Table 6 . As can be seen, more than 60 percent of total firms answered planning to invest in machinery/equipment over the next two years. With respect to credit availability, of all firms only one fifth has a bank loan. Access to bank credit increases with firm size.

The bottom part of Table 6 provides evidence on a positive relationship between productivity and access to bank credit. The level of productivity is higher for firms with bank credit than for other firms, no matter the size of the firm. More importantly, productivity differences are larger for

\footnotetext{
10 Question number 9.24 on the ENAFIN questionnaire asks the following: "Is the firm planning to buy machinery/equipment in the next two years?"
} 
smaller firms. This finding may suggest that bank credit has a bigger impact on the productivity of firms with fewer credit alternatives.

Table 6. Productivity of Firms with Plans to buy Machinery/Equipment in the Next 2 Years with and without Bank Credit

\begin{tabular}{|c|c|c|c|c|c|}
\hline Variable & Micro & Small & Medium & Large & Al1 \\
\hline \multicolumn{6}{|c|}{ Percentage of Firms } \\
\hline $\begin{array}{l}\text { Firms with plans to buy } \\
\text { machinery/equipment in } \\
\text { the next } 2 \text { years }\end{array}$ & 59.2 & 62.2 & 57.8 & 66.2 & 61.0 \\
\hline Firms with bank credit & 9.3 & 23.5 & 30.4 & 33.6 & 20.7 \\
\hline $\begin{array}{l}\text { Firms with bank credit } \\
\text { and plans to buy } \\
\text { machinery/equipment in } \\
\text { the next } 2 \text { years }\end{array}$ & 6.6 & 16.3 & 21.2 & 26.1 & 12.2 \\
\hline \multicolumn{6}{|c|}{ Productivity } \\
\hline $\begin{array}{l}\text { Firms with bank credit and } \\
\text { plans to buy } \\
\text { machinery/e quipment in } \\
\text { the next } 2 \text { years }\end{array}$ & 13.3 & 12.4 & 13.0 & 12.6 & 12.7 \\
\hline $\begin{array}{l}\text { Firms without bank cre dit } \\
\text { and plans to buy } \\
\text { machinery/equipment in } \\
\text { the next } 2 \text { years }\end{array}$ & 11.6 & 11.6 & 12.7 & 12.3 & 11.9 \\
\hline
\end{tabular}

Notes: productivity is in logs; see Appendix for definitions and source of variables.

\section{Results}

Table 7 reports the final estimates of specification (2). The specification controls for firm characteristics and factors that affect productivity as described in the previous section. In all estimates, labor productivity is the dependent variable. There are 369 available observations for which there are non-missing data. Details of the econometric estimate are described at the bottom of Table 7 .

Equations (1) to (3) were estimated by OLS, identifying firms with investment opportunities as those firms with plans to buy machinery/equipment in the next two years. Firms with bank credit have loans, revolving facilities, or both. As can be seen in Table 7, the coefficient estimate for the interaction term is positive and statistically significant at the 1-percent level (in all estimates, the reported standard errors are robust to heteroscedasticity). This result supports the hypothesis that bank credit enhances the productivity of firms with investment opportunities. 
The relevance of this result may be questioned, because the parameter may be biased due to an endogeneity problem. Banks may grant loans to the more productive firms, so bank credit flows to more productive firms not enhancing productivity. To address this issue, a variable indicating firms that pledge collateral is used as an instrument for firms with bank credit. The correlation between firms with collateral and bank credit is high (85 percent), but the correlation between firms with collateral and their productivity level is not statistically significant. This is particularly true for small-sized and new firms, where their productivity has no relation with their lack of available properties or assets to pledge against loans. Furthermore, lack of collateral is as a well-known answer by owners of small businesses to explain their lack of interest in applying for bank loans (Kon and Storey, 2003; Chakravarty and Xiang, 2009). Collateral is correlated with bank credit, but not otherwise correlated with productivity; this variable seems to be an adequate instrument for firms with bank credit.

The result that bank credit enhances productivity may also be questioned because firms with investment opportunities are not being correctly identified. An alternative way to identify firms with investment opportunities is through their consumption of energy and use of communication services. Firms with prospects of an increase in demand are likely to increase their consumption of electricity and make more phone calls. On the contrary, a firm with a lack of investment opportunities would save on utility costs. Firm spending on utilities is used as an instrument for investment opportunities. ${ }^{11}$ The correlation between utility costs and investment opportunities is 82 percent and with productivity 23 percent.

Table 7 shows the estimated parameters of specification (2) using firms with collateral and firms' utility costs as instruments for bank credit and investment opportunities, respectively. As can be seen, the results coincide with OLS estimates. The coefficient estimate for the interaction term is positive and statistically significant at the 1-percent level. More important, this parameter is consistent across estimates and varies in a range of 0.403 to 0.503 . These results suggest that firms with access to bank credit and investment opportunities are 50 percent more productive than other firms. ${ }^{12}$

11 Utilities include consumption of electricity, telephone and internet service and rent of business space.

12 This percentage is obtained by multiplying the interaction term by the average productivity difference between firms with bank credit and investment opportunities and other firms. 
Table 7. Estimate Results of Specification (2)

\begin{tabular}{|c|c|c|c|c|c|}
\hline \multirow{3}{*}{ Variable } & \multicolumn{5}{|c|}{ Dependent variable: labor productivity } \\
\hline & \multicolumn{3}{|c|}{ OLS } & \multicolumn{2}{|c|}{ IV } \\
\hline & (1) & (2) & (3) & (4) & (5) \\
\hline $\begin{array}{l}\text { Interaction term (investment } \\
\text { opportunities } x \text { b ank credit) }\end{array}$ & $\begin{array}{c}0.486^{* * * *} \\
(0.116)\end{array}$ & $\begin{array}{c}0.408^{* * *} \\
(0.121)\end{array}$ & $\begin{array}{l}0.489^{* * *} \\
(0.121)\end{array}$ & $\begin{array}{c}0.503^{* * * *} \\
(0.134)\end{array}$ & $\begin{array}{c}0.403^{* * *} \\
(0.132)\end{array}$ \\
\hline \multirow[t]{2}{*}{ Formality } & $1.084^{* * * *}$ & $0.954^{* * * *}$ & $0.858^{* * * *}$ & $0.958^{* * * *}$ & $0.861^{* * * *}$ \\
\hline & $(0.112)$ & $(0.126)$ & $(0.134)$ & $(0.125)$ & $(0.131)$ \\
\hline \multirow[t]{2}{*}{ Age } & & $0.156^{*}$ & 0.121 & $0.158 *$ & 0.120 \\
\hline & & $(0.199)$ & $(0.094)$ & $(0.095)$ & $(0.092)$ \\
\hline \multirow[t]{2}{*}{ Small firm } & & -0.097 & 0.027 & -0.114 & -0.019 \\
\hline & & $(0.194)$ & $(0.189)$ & $(0.200)$ & $(0.187)$ \\
\hline \multirow[t]{2}{*}{ Medium firm } & & $0.450^{*}$ & 0.395 & $0.390 *$ & 0.339 \\
\hline & & $(0.279)$ & $(0.278)$ & $(0.282)$ & $(0.278)$ \\
\hline \multirow[t]{2}{*}{ Large firm } & & 0.371 & $0.475 * *$ & $0.318^{*}$ & $0.421^{*}$ \\
\hline & & $(0.236)$ & $(0.228)$ & $(0.235)$ & $(0.228)$ \\
\hline \multirow[t]{2}{*}{ Familiy-owned firm } & & $-(0.059)$ & & & \\
\hline & & $(0.217)$ & & & \\
\hline \multirow[t]{2}{*}{ Export-oriented firm } & & $0.838^{* * * *}$ & $0.669 * * *$ & $0.866^{* * * *}$ & $0.695^{* * * *}$ \\
\hline & & $(0.240)$ & $(0.224)$ & $(0.233)$ & $(0.221)$ \\
\hline \multirow[t]{2}{*}{ Industry } & & & $0.375^{* * *}$ & & $0.344^{* * *}$ \\
\hline & & & $(0.161)$ & & $(0.160)$ \\
\hline \multirow[t]{2}{*}{ Trade } & & & $0.953^{* * * * 4}$ & & $0.908^{* * * *}$ \\
\hline & & & $(0.235)$ & & $(0.233)$ \\
\hline \multirow[t]{2}{*}{ Constant } & $7.733^{* * * *}$ & $7.754^{: * * *}$ & $7.786^{* * * *}$ & $7.690^{: * * *}$ & $7.801^{*: * *}$ \\
\hline & $(0.482)$ & $(0.483)$ & $(0.485)$ & $(0.445)$ & $(0.473)$ \\
\hline $\mathbf{R}^{2}$ & 0.215 & 0.268 & 0.309 & 0.265 & 0.308 \\
\hline Number of observations & 369 & 351 & 353 & 353 & 353 \\
\hline
\end{tabular}

*** Significant at the 1 percent level; ** at the 5 percent level; * at the 10 percent level. Standard errors in parenthesis.

Notes to Table 7: Labor productivity is measured as the log of output per employee; output is equal to sales income deflated by its respective sector producer price index; the formality index has a range of 0 to 8 , where 8 is totally formal; investment opportunities refers to question number 9.24 on the ENAFIN questionnaire that asks the following: "Is the firm planning to buy machinery/equipment in the next two years?"; bank credit is a dichotomous $(0,1)$ variable where 1 indicates the firm has a loan or a revolving credit facility from a commercial bank; age is measured as the log of years of the firm in the market; firm size is defined by the number of employees; family-owned businesses are firms where owners or their relatives are general managers; export-oriented firms are those with 50 percent or more of their sales abroad; industry and trade sectors are dichotomous variables $(1,0)$; regressions (1) to (3) are estimated with OLS; regressions (4) and (5) are estimated with instrumental variables; workers' years of educations were highly correlated with firm size, so this was omitted from the final estimates; instrumental variables are bank credit and firms that have investment opportunities with firms with guarantees and utility expenses, respectively; the validity of these instruments is corroborated by implementing the Hausman test; in all estimates the errors are heteroscedasticity-robust standard errors; there are 369-351 available observations for which data are not missing. Regressions are estimated with unweighted sample observations because the interest lay in the relationship between the independent and dependent variables (Cameron and Trivedi, 2005). 


\section{Conclusion}

The idea that credit promotes productivity is common sense among entrepreneurs. Credit allows many productive firms to expand or make technological improvements and investments needed to increase their productivity beyond what their internal funds can support. Under these conditions, credit is efficiently assigned. However, the absence of investment opportunities may lead firms to divert credit to non-investment uses, for instance financing daily operations. Thus, the channel of transmission from credit to productivity is efficiency.

This paper utilized a recent survey of Mexican firms to provide evidence of the positive effect of bank credit on productivity for those firms with investment opportunities. These firms -with access to bank credit and investment opportunities- are 50 percent more productive than other firms. The potential problem of endogeneity in the empirical estimates is addressed by finding instruments for the main explanatory variables and estimating with IV. The relevant parameter indicating a positive effect of bank credit to productivity is constant among estimates and estimation techniques.

\section{Appendix}

The data used in the current study comes from the Survey of Enterprises on Competitiveness, Financing and Use of Financial Services ${ }^{13}$ (ENAFIN) (Encuesta Nacional de Competitividad, Fuentes de Financiamiento y Uso de Servicios Financieros de las Empresas $)^{14}$ conducted by the Banking and Securities Supervisory Agency (Comisión Nacional Bancaria y de Valores) and the International Development Bank (IDB) with respect to information on firms' financing sources. The survey collected information for 2009 on 986 non-financial firms with more than 5 employees in localities with at least 50 thousand inhabitants. The ENAFIN collected information on firms' characteristics on age, formality compliance, decision-makers in the firm, business income and expenses; financing sources and terms, and access and use of financial services. Firms are grouped in four size-categories (micro, small, medium and large) according to the number of employees (Table 7).

\footnotetext{
13 "Encuesta Nacional de Competitividad, Fuentes de Financiamiento y Uso de Servicios Financieros de las Empresas".

14 Data is available at the following internet address: http://www.cnbv.gob.mx/Prensa/Estudios/Base\%20ENAFIN_website_.dta
} 
Table 8. Firm Size Categories by Number of Employees and Number of Firms included in the ENAFIN

\begin{tabular}{|lcccc|}
\hline Firm size & \multicolumn{3}{c}{ Number of employees } & $\begin{array}{c}\text { Total number } \\
\text { of firms }\end{array}$ \\
\cline { 2 - 4 } Micro & Trade & Services & Ind ustry & \\
\hline Small & 6 to 10 & 6 to 10 & 6 to 10 & 367 \\
Medium & 11 to 30 & 11 to 50 & 11 to 50 & 328 \\
Large & 31 to 100 & 51 to 100 & 51 to 250 & 148 \\
\hline T otal number of firms & 101 or more & 101 or more & 251 or more & 143 \\
\hline
\end{tabular}

Table 9. Definitions and Source of Variables from ENAFIN

\begin{tabular}{|c|c|}
\hline Firm Variables & Question number \\
\hline Number of employees & $\begin{array}{l}\text { Q. } 1.01 \text {. "En } 2009 \text { ccuántos empleados tuvo la emprexa o negocio (inchuyendo } \\
\text { personal administrativo)? Por favor indique cuántos empleados son permanentes y } \\
\text { cuántos temporales en este estableciniento". }\end{array}$ \\
\hline Sales income & $\begin{array}{l}\text { Q } 9.02 \text { En } 2009 \text {, apror inadamente jcual fue el monto de sus ingrexos anuales por } \\
\text { ventas? }\end{array}$ \\
\hline Outpot & Sales income deflated by producer price indices \\
\hline Investment opportunities & Q 9.24 ¿Planea conprar maquinaria y/oequipo en los prór inos 2 años? \\
\hline Collateral & $\begin{array}{l}\text { Q } 15.12 \text { Aportó alguna grantía por esta línea de crédito? } \\
\text { Q } 16.13 \text { Aporti alguna garantia por este crédito de largo plazo además del bien que } \\
\text { adquirio? }\end{array}$ \\
\hline Utilities expense & 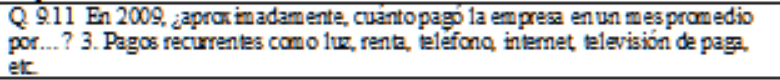 \\
\hline $\begin{array}{l}\text { Age } \\
\text { Family-owned }\end{array}$ & $\begin{array}{l}\text { Q 207. ¿Cúintos años tiene esta enpresa (negocio) operandoen su actividad } \\
\text { principal? } \\
\text { Q } 202 \text { ¿Es esta una enpresa (negocio) fam iliar? }\end{array}$ \\
\hline $\begin{array}{l}\text { Owner is general } \\
\text { manager }\end{array}$ & $\begin{array}{l}\text { Q } 203 \text { iEl director de esta enpresa (negocio) es también el duenoprincipal osocio } \\
\text { de la misma? }\end{array}$ \\
\hline External participation & $\begin{array}{l}\text { Q } 205 \text { ¿Otra compaña o grupo ecconón ico es dueña de más de } 150 \% \text { de esta } \\
\text { enpresa (negocio)? }\end{array}$ \\
\hline Fiscal regime & 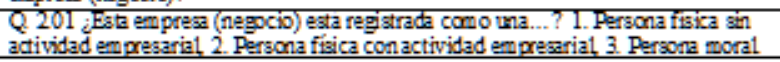 \\
\hline $\begin{array}{l}\text { Registry of business } \\
\text { Operations }\end{array}$ & $\begin{array}{l}\text { Q } 208208 \text { ¿Esta enprexa (negocio)...? } \\
\text { 1. No lleva ningin registro contable } \\
\text { 2. E1 dueholleva sus cuentas personalmente } \\
\text { 3. Acude ocventa con los servicios de un contad } \alpha \text { oprofesional para llevar las } \\
\text { cuentas } 4 \text { Utiliza la caja registradora de la Secretaria de Hacienca. }\end{array}$ \\
\hline Sales receipts & $\begin{array}{l}\text { Q } 209 \text { Qué tipo de conprobantes expide esta empresa (negocio) a sus clientes?1 } \\
\begin{array}{ll}\text { Facturas } 2 \text { Recibos } & \text { 3. Facturas y recibos, 4. Ninguno de los anteriores. }\end{array}\end{array}$ \\
\hline Business licensing & 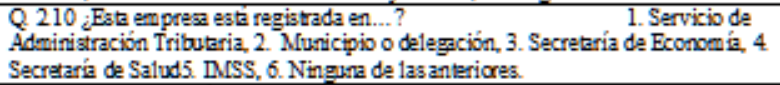 \\
\hline Foreign sales & $\begin{array}{l}\text { Q } 9.03 \text { En } 2009 \text {, qué porcentaje de sus ingesos por venta de productos o servicios } \\
\text { æe destinó a mercados en el extranjero? }\end{array}$ \\
\hline \multirow[t]{3}{*}{ Bank credit } & $\begin{array}{l}\text { Questions } 15.01,15.02,1601 \text { and } 16.02 \text {. } \\
15.01 \text { Al cierre de } 2009 \text {, cual fue el saldo total de deude de la empresa en todas las } \\
\text { lineas de cridito vigentes? }\end{array}$ \\
\hline & $\begin{array}{l}15.02 \text { Duranta el periodo } 2005-2009 \text {, ¿cuántas líneas de crédito revolvente obtuvo la } \\
\text { enpresa? }\end{array}$ \\
\hline & 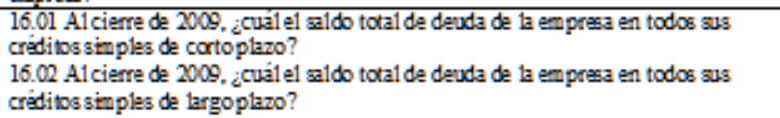 \\
\hline
\end{tabular}


210 Nueva Época REMEF (The Mexican Journal of Economics and Finance)

\section{References}

Abowd, J., J. Haltiwanger, R. Jarmin, J. Lane, P. Lengermann, K. McCue, K. McKinney and K. Sandusky (2002). The Relation Among Human Capital, Productivity, and Market Value: Building Up from Micro Evidence, Technical Paper no. TP-2002-14 US Census Bureau, LEHD Program, U.S.A.

Alfaro, L., A. Charlton and F. Kanczuk (2008). Plant-Size Distribution and Cross-Country income differences, W.P. number 14060, NBER, U.S.A.

Baily, M. N. and R. M. Solow (2001). International Productivity Comparisons built from the Firm Level, Journal of Economic Perspectives, 15(3), Summer, pp. 151-172.

Baily, M. N., E. J. Bartelsman and J. Haltiwanger (2001). Labor productivity: Structural Change and Cyclical Dynamics, Review of Economics and Statistics, 83(3), august, pp. 420-433.

Bartelsman, E. J. and M. Doms (2000). Understanding Productivity: Lessons from Longitudinal Microdata, Journal of Economic Literature, 38, September, pp. 569-594.

Berger, A. N. and G. F. Udell (1995). Relationship Lending and Lines of Credit in Small Firm Finance, Journal of Business, 68(3), 351-381.

Bernand, A. B., J. Eaton, J. B. Jensen and S. S. Kortum (2003). Plants and Productivity in International Trade, American Economic Review, 93(4), pp. 1268-1290.

Bloom, N., A. Mahajan, D. McKenzie and J. Roberts (2010). When Do Firms in Developing Countries Have Low Productivity, American Economic Review, 100(2), pp. 619-623.

Butler, A. W. and J. Cornaggia (2007), Does Access to Finance Improve Productivity? Evidence from a Natural Experiment, W.P. University of Texas.

Cameron, A. C. and P. K. Trivedi (2005). Microeconometrics. Methods and Applications, Cambridge University Press, U.K.

Chakravarty, S. and M. Xiang (2009). What Discourages Small Businesses from Asking for Loans? The International Evidence on Borrower Discouragement, W.P., Purdue University.

Comisión Nacional Bancaria y de Valores (CNBV) and Banco Interamericano de Desarrollo (BID) (2009). Encuesta Nacional de Competitividad, Fuentes de Financiamiento y Uso de Servicios Financieros de las Empresas.

De Gregorio, J. and P. E. Guidotti (1995). Financial Development and Economic Growth, World Development, 23(3), pp. 433-448.

Easterly, W. (2001). The Elusive Quest for Growth, World Bank, U.S.A.

Ghani, E. and V. Suri (1999). Productivity Growth, Capital Accumulation, and the Banking Sector: Some Lessons from Malaysia, W.P. number 2252, World Bank.

Gatti, R. and I. Love (2006). Does Access to Credit Improve Productivity? Evidence from Bulgarian firms, W.P. No. 3921, World Bank.

Hsieh, C. and P. J. Klenow (2009). Misallocation and Manufacturing TFP in China and India, Quarterly Journal of Economics, 124(4), November, pp. 1403-1448.

Hurst, E. and B. Wild Pugsley (2011). What Do Small Businesses Do?, W.P. 17041, NBER, U.S.A.

Keasey, K. and P. McGuinness (1990). Small New Firms and the Return to Alternative Sources of Finance, Small Business Economics, 2, pp. 213-222.

Kon, Y. and D. Storey (2003). A Theory of Discouraged Borrowers, Small Business Economics, 21(1), pp. 37-49.

Lora, E. and C. Pages (2011). Face-to-Face with Productivity, Finance and Development, 48(1), pp. 16-19.

Leff, N. H. (1979). Entrepreneurship and Economic Development: The Problem Revisited, Journal of Economic Literature, 17, March, pp. 46-64.

Leung, D., C. Meh and Y. Terajima (2008). Firm Size and Productivity, W.P. Number 45, Bank of Canada, Canada.

Melitz, M. J. (2003). The Impact of Trade on Intra-Industry Reallocations and Aggregate Industry Productivity, Econometrica, 71(6), pp. 1695-1725.

Maury, B. (2006). Family Ownership and Firm Performance: Empirical Evidence from Western European Corporations, Journal of Corporate Finance, 12, pp. 321-341. 
Myers, S. C. (1984). The Capital Structure Puzzle, Journal of Finance, pp. 575-592.

Pages, C. (ed.) (2010). La era de la productividad: cómo transformar las economías desde sus cimientos, Banco Interamericano de Desarrollo, México.

Rajan, R. G. and L. Zingales (1998). Financial Dependence and Growth, American Economic Review, 88(3), June, pp. 559-586.

Rajan, R. G. and L. Zingales (2003). Saving Capitalism from the Capitalists. Unleashing the Power of Financial Markets to Create Wealth and Spread Opportunity, Crown Business, New York, U.S.A.

Schiantarelli, F. and F. Jaramillo (1999). Access to Long-Term Debt and Effects on Firms' Performance: Lessons from Ecuador," W.P. number 1725, World Bank.

Tybout, J. and M. Roberts (1997). The Decision to Export in Colombia: An Empirical Model of Entry with Sunk Costs, American Economic Review, 87(4), pp. 545-563. 


\section{INSTRUCCIONES PARA LOS AUTORES}

1) La Revista Mexicana de Economía y Finanzas (REMEF) es una publicación semestral que recibe trabajos de investigación en finanzas, economía y temas de la actividad empresarial.

2) Los trabajos de investigación que se sometan a REMEF deben ser originales, inéditos y de carácter científico. La publicación del artículo implica la cesión total de los derechos de propiedad (copyright) a la REMEF. La revista se reserva el derecho para la reproducción total o parcial del trabajo en otros medios impresos y/o electrónicos.

3) Todo trabajo de investigación que reciba REMEF estará sujeto a la revisión de dictaminadores anónimos externos. El trabajo de investigación sólo se aceptará con dos dictámenes positivos. Los resultados de los dictámenes se entregarán a los autores en no más de dos meses después de la recepción del trabajo. Toda controversia la resolverá el Consejo Editorial, cuya decisión es inapelable.

4) Los artículos pueden ser escritos en español o inglés y deben incluir un resumen en ambos idiomas. En caso de aceptación de artículos en inglés, el autor será totalmente responsable de la forma de estilo y consistencia (inglés británico o norteamericano) del documento.

5) Los trabajos de investigación que se sometan no pueden ser enviados simultáneamente a otras revistas.

6) Los trabajos de investigación se reciben en cualquier editor de texto (Word, TEX, Latex, Scientific Word, etc.) en no más de 25 cuartillas a espacio seguido, incluyendo cuadros y gráficas. Los trabajos pueden ser enviados al correo electrónico: remef@imef.org.mx

7) La primera página debe contener: a) título del trabajo; b) nombre(s) del (de los) autores; c) institución de adscripción; d) resumen de no más de 100 palabras en español (lo mismo para el abstract); e) palabras clave (máximo 5) y clasificacion JEL; f) pie de página con dirección, teléfono y correo electrónico del autor que recibirá correspondencia.

8) Gráficas, cuadros y fórmulas se numerarán consecutivamente.

9) La bibliografía debe presentarse al final, de acuerdo con los siguientes ejemplos:

Fuller, W. A. (1996). Introduction to Statistical Time Series. 2nd ed., John Wiley, New York.

Granger, C. W. (1980). Long Memory Relationships and the Aggregation of Dynamics Models. Journal of Econometrics, 14, pp. 227-238.

Duffy, J. (2001). Learning to Speculate: Experiments with Artificial and Real Agents. Journal of Economic Dynamics and Control, 25(3), pp. 295-319.

Arifovic, J., J. Bullard, and J. Duffy (1997). The Transition from Stagnation to Growth: An Adaptive Learning Approach. Journal of Economic Growth, 2, pp. 185-209.

10) La revista se reserva el derecho de incorporar los cambios de formato que considere pertinentes

Los artículos de REMEF aparecen listados y/o resumidos en Latindex, EconLit, EconPapers-RePEc, Dialnet y Ulrich's. 


\section{SUBMISSION GUIDELINES}

1) The Mexican Journal of Economics and Finance (REMEF) is a peer reviewed indexed journal issued every six months; it publishes leading research articles in Finance, Economics and Business issues.

2) Papers submitted to the journal must be original, unpublished scientific documents. The text of accepted papers, or any part thereof, may not be reproduced in any form or by any means, electronic or mechanical, without prior permission of the publisher.

3) Submitted manuscripts will subject to a blind external refereeing process and will be only accepted with two positive opinions. Refereeing results will be delivered within two months following reception of the document. Negative results can be appealed to the Editorial Committee which will give a final decision.

4) Papers can be written in either Spanish or English. The names and affiliations of the authors should not be included in the text of the manuscript. After the title, each manuscript must contain an abstract in both languages and the JEL Classification and at most 5 keywords. The style is ultimate responsibility of the authors who additionally are responsible for all contents and ideas presented in the document.

5) Manuscripts should not be submitted simultaneously to any other journal.

6) Manuscripts should be all presented in any text editor (Word, TeX, LaTeX, Scientific Word, etc.) in no more than 25 pages typed in single space, including tables, figures and references. The papers are to be sent by email: remef@imef.org.mx

7) The cover page should contain: a) title, b) the name(s) of the author(s), c) institutional affiliation(s); d) abstract of no more than 100 words in English and Spanish: e) keywords (no more than 5) and Jel Classification; f) footnote of address, telephone and email of the corresponding author.

8) Figures, tables and formulas should be numbered consecutively in Arabic numbers.

9) References should be listed at the end of the paper in alphabetical order employing the following examples:

Fuller, W. A. (1996). Introduction to Statistical Time Series. 2nd ed., John Wiley, New York.

Granger, C. W. (1980). Long Memory Relationships and the Aggregation of Dynamics Models. Journal of Econometrics, 14, pp. 227-238.

Duffy, J. (2001). Learning to Speculate: Experiments with Artificial and Real Agents. Journal of Economic Dynamics and Control, 25(3), pp. 295-319.

Arifovic, J., J. Bullard, and J. Duffy (1997). The Transition from Stagnation to Growth: An Adaptive Learning Approach. Journal of Economic Growth, 2, pp. 185-209.

10) The Journal reserves the right to incorporate appropriate formatting changes.

The articles in REMEF are listed and/or summarized in Latindex, EconLit, EconPapers-RePEc, Dialnet and Ulrich's. 